\title{
No changes in lymphocyte muscarinic receptors and platelet monoamine oxidase-B examined as surrogate central nervous system biomarkers in a Faroese children cohort prenatally exposed to methylmercury and polychlorinated biphenyls
}

\section{Citation}

Coccini, Teresa, Luigi Manzo, Frodi Debes, Ulrike Steuerwald, Pál Weihe, and Philippe Grandjean. 2009. "No Changes in Lymphocyte Muscarinic Receptors and Platelet Monoamine Oxidase-B Examined as Surrogate Central Nervous System Biomarkers in a Faroese Children Cohort Prenatally Exposed to Methylmercury and Polychlorinated Biphenyls." Biomarkers 14 (2) (March): 67-76. doi:10.1080/13547500902783739.

\section{Published Version}

doi:10.1080/13547500902783739

\section{Permanent link}

http://nrs.harvard.edu/urn-3:HUL.InstRepos:34786425

\section{Terms of Use}

This article was downloaded from Harvard University's DASH repository, and is made available under the terms and conditions applicable to Other Posted Material, as set forth at http:// nrs.harvard.edu/urn-3:HUL.InstRepos:dash.current.terms-of-use\#LAA

\section{Share Your Story}

The Harvard community has made this article openly available.

Please share how this access benefits you. Submit a story.

\section{Accessibility}




\title{
No changes in lymphocyte muscarinic receptors and platelet monoamine oxidase-B examined as surrogate central nervous system biomarkers in a Faroese children cohort prenatally exposed to methylmercury and polychlorinated biphenyls
}

\author{
Teresa Coccini ${ }^{1}$, Luigi Manzo ${ }^{1,2}$, Frodi Debes ${ }^{3}$, Ulrike Steuerwald ${ }^{3}$, Pál Weihe ${ }^{3}$, and \\ Philippe Grandjean ${ }^{4,5}$
}

${ }^{1}$ IRCCS Salvatore Maugeri Foundation, Toxicology Division, Institute of Pavia, Italy ${ }^{2}$ University of Pavia, Department of Internal Medicine and Therapeutics, Toxicology Division, Pavia, Italy ${ }^{3}$ Department of Occupational and Public Health, Faroese Hospital System, Torshavn, Faroe Islands ${ }^{4}$ University of Southern Denmark, Institute of Public Health, Department of Environmental Medicine, Odense C, Denmark ${ }^{5}$ Harvard School of Public Health, Department of Environmental Health, Boston, MA, USA

\begin{abstract}
Experimental evidence suggests that monoamine oxidase B (MAO-B) and muscarinic cholinergic receptors (mAChRs) are involved in the pathogenesis of neurotoxicity caused by methylmercury and polychlorinated biphenyls (PCBs). Blood samples from 7-year-old exposed children were analyzed for platelet MAO-B and lymphocyte mAChRs as potential markers of exposure to these neurotoxicants. The blood neurotoxicity biomarkers were compared with prenatal and current exposures and with neuropsychological test results. Both biomarkers showed homogeneous distributions within this cohort (mAChR, range 0.04-36.78 fmol/million cells; MAO-B, 0.95$14.95 \mathrm{nmol} \mathrm{mg}^{-1}$ protein $\mathrm{h}^{-1}$ ). No correlation was found between the two biomarkers and either blood neurotoxicant concentrations or clinical findings. MAO-B and mAChR sensitivity may not be sufficiently high to assess early, subclinical responses to low/moderate methylmercury and/or PCB exposure, whereas these markers are significantly altered in sustained exposure scenarios, as shown by clinical studies in drug addicts or patients treated with psychopharmacological agents.
\end{abstract}

\section{Keywords}

Neurochemical markers; MeHg; polychlorinated biphenyls; brain development; MAO-B; cholinergic receptors

\section{(C) 2009 Informa UK Ltd}

Address for Correspondence: Teresa Coccini, Toxicology Division, Institute of Pavia, IRCCS Salvatore Maugeri Foundation, Via Maugeri 10, 27100 Pavia, Italy. Tel.: +39-0382-592416. Fax: +39-0382-24605. teresa.coccini@ fsm.it.

Declaration of interest: The authors report no conflicts of interest. The authors alone are responsible for the content and writing of the paper. 


\section{Introduction}

Among the neurotoxicants known to cause developmental brain damage in humans are methylmercury ( $\mathrm{MeHg}$ ) and polychlorinated biphenyls (PCBs), both occurring widely as seafood contaminants (Castoldi et al. 2008, Jacobson \& Jacobson 1997). However, even for these pollutants, the dose-response relationships are unclear, particularly in relation to concomitant exposures, and the specific identity of PCB congeners causing the PCBassociated neurotoxicity remains to be determined. While the overall health significance of developmental neurotoxicity has been poorly documented so far, it is clear that permanent and serious brain damage can occur as a result of exposures occurring early in life, i.e. prenatally and during early postnatal life (Rodier 1994, Rice \& Barone 2000, Grandjean \& Landrigan 2006).

Studies of neurobehavioural endpoints in children exposed to PCBs or MeHg show that persistent deficits during infancy and school age are associated with transplacental exposure as an indication that the fetal brain is a sensitive target organ for the toxic effects of these compounds (Grandjean \& Landrigan 2006). A birth cohort established in the Faroe Islands, a fishing community in the North Atlantic Ocean, showed mercury-related neuropsychological deficits, especially in the domains of language, attention and memory, and to a lesser extent in visuospatial and motor functions (Grandjean et al. 1997). These associations may have been augmented by concomitant exposure to PCBs, which may affect similar neurobehavioural endpoints (Grandjean et al. 2001, Stewart et al. 2003).

Evaluating the effects of exposure to combinations of neurotoxicants is extremely difficult in epidemiological studies. In this respect, parallel studies correlating exposure parameters and indicators of neural cell function may represent a promising strategy. Several biochemical and molecular parameters measurable in peripheral blood cells have been investigated as non-invasive surrogate markers for particular CNS alterations associated with neuropsychiatric disorders or induced by neurotoxicants (Manzo et al. 1996, 2001). Examples of these peripheral markers include the cholinergic muscarinic receptors (mAChRs) in lymphocytes and the enzyme activity of monoamine oxidase-B (MAO-B) in platelets (Manzo et al. 2001).

The cholinergic system is a sensitive target for MeHg neurotoxicity (Yuan \& Atchison 1993, Limke et al. 2004). In vitro experiments have indicated that $\mathrm{MeHg}$ acts as a strong competitive inhibitor of radioligand binding to mAChRs in the rat (Castoldi et al. 1996) and human brain tissue (Basu et al. 2005). Brain mAChRs share several pharmacological characteristics of similar receptors present on lymphocytes and parallel changes in the density of mAChRs have been shown to occur in lymphocytes and brain tissue following exposure to pharmacological agents and neurotoxicant chemicals acting at the cholinergic system (Coccini et al. 2000, Costa et al. 1990, Fitzgerald \& Costa 1993). MeHg was shown to alter cerebral mAChR density both in brain and lymphocytes following repeated oral administration to adult rats with changes in peripheral $\mathrm{mAChR}$ binding even preceding those observed in brain (Coccini et al. 2000, 2006). Moreover, perinatal MeHg exposure can enhance the lymphocyte mAChR density in rats (Coccini et al. 2007a), thus supporting the use of this endpoint as a peripheral marker of $\mathrm{MeHg}$-induced cerebral cholinergic alterations 
in the developing organism. It has been shown that rat brain mAChRs can also be affected by PCBs during development (Eriksson et al. 1991, Coccini et al. 2006, 2007b). Notably, co-exposure to MeHg and either PCB153 or PCB126 had the same effect on the cerebral mAChRs as exposure to each compound alone (Castoldi et al. 2006).

Both MeHg and PCBs may also affect MAO activity, which is implicated in the degradation of monoamine neurotransmitters, and which plays an important role in neurochemical regulation of behaviour. The MAO-B isoenzyme is the predominant form in the human brain and the sole type present in human platelets. The amino acid sequences of MAO-B in both platelets and brain are identical (Chen et al. 1993), and the biochemical and pharmacological characteristics of the enzyme are also similar in the two tissues (Donnelly \& Murphy 1977). For these reasons, platelet MAO has been widely used as a model of central neuronal function and a peripheral marker to investigate neurological and psychiatric disorders (Wyatt et al. 1973, Fowler et al. 1982, Whitfield et al. 2000, Coccini et al. 2002). In laboratory models, $\mathrm{MeHg}$ was shown to inhibit $\mathrm{MAO}$ activity both in vivo and in vitro (Chakrabarti et al. 1998, Beyrouty et al. 2006), and prenatal exposure to PCB77 depressed postnatal development of MAO activity in whole rat brain (Vincent et al. 1992). Recent studies indicated that perinatal exposure to $\mathrm{MeHg}$ or PCB153 induces regional alterations of the rat central dopaminergic and serotonergic systems at weaning, but the combined treatment with $\mathrm{MeHg}$ and PCB153 does not exacerbate the neurochemical effects of the individual compounds (Castoldi et al. 2006).

In the present study, lymphocyte $\mathrm{mAChRs}$ and MAO-B activity have been investigated in 7year-old children from a Faroese birth cohort, wherein prenatal exposures to MeHg and PCB had already been characterized (Steuerwald et al. 2000).

\section{Material and methods}

The Faroese birth cohort $(n=182)$ was established in 1994-95 and consisted of singleton term births. The studies adhered to the Declaration of Helsinki and have been performed after approval of the Faroese ethical review committee. All subjects participating in the clinical studies have been included after parental written informed consent. Of the original 182 cohort members, 177 were eligible for participation in the 7-year examinations, and 166 agreed to participate (94\%). A total of 159 children ( 76 boys, 83 girls) completed their examinations at 7 years of age with a voluntary blood sample for the exposure analyses and for the determination of biochemical markers.

\section{Exposure assessment}

Because both prenatal and postnatal exposures may be of concern, exposure assessment utilized previous analyses of maternal serum and milk for PCBs and maternal hair and cord blood for mercury (Steuerwald et al. 2000). The blood collected from the children at age 7 years was analyzed for mercury (whole blood) and PCBs (serum). To avoid dependence on PCB congeners that would be non-detectable in some samples, the total PCB concentration was calculated as the sum of the major PCB congeners 138, 153 and 180 multiplied by 2 (Grandjean et al. 2001). Total Hg determination in blood was assessed following the procedure previously described (Grandjean et al. 2005). 


\section{Neurochemical markers}

Lymphocyte mAChR binding and platelet MAO-B activity were measured in 139 and 137

blood children samples, respectively, without knowledge of exposure levels or other relevant data. Parallel in vitro assays using platelets or lymphocytes from healthy subjects were performed to determine the lowest-observed-adverse-effect-level (LOAEL) values and concentration-response curves for MAO-B and $\mathrm{mAChRs}$ in cell preparations treated with $\mathrm{MeHg}$ and various PCB congeners. The analyses were performed according to the Certification programme for the quality assurance UNI EN ISO 9001:2000 in laboratory medicine.

Isolation and long-lasting storage of blood cells-Blood was collected in EDTA tubes and immediately processed to isolate lymphocytes for $\mathrm{mAChR}$ binding or platelets for MAO-B activity as previously described (Coccini et al. 2005). The lymphocytes were resuspended in the freezing solution ( $90 \%$ plasma obtained from autologous blood kept on ice $+10 \%$ dimethylsulfoxide (DMSO)), while the platelet-rich plasma (PRP) was diluted with $10 \%$ DMSO. Immediately after, the cells were gradually frozen at $-80^{\circ} \mathrm{C}$ for $24 \mathrm{~h}$ and thereafter stored in liquid nitrogen.

Chemicals- $\left[{ }^{3} \mathrm{H}\right]$-Quinuclidinyl benzilate $\left(\left[{ }^{3} \mathrm{H}\right] \mathrm{QNB}\right)\left(49 \mathrm{Ci} \mathrm{mmol}^{-1}\right)$ and scintillation fluid Biofluor were obtained from NEN Life Sciences Products (Boston, MA, USA), while ${ }^{14} \mathrm{C}$-PEA (ethyl-1- ${ }^{14} \mathrm{C}$-phenylethylamine hydrochloride, $41.8 \mathrm{mCi} \mathrm{mmol}^{-1}$ ) from Du Pont de Nemours (Florence Italy). All the other chemicals were purchased from SigmaAldrich (Milan, Italy).

The PCBs used for the in vitro studies (PCB-28, PCB-77, PCB-105, PCB-115, PCB-153 and 4-OH-CB-107) were synthesized and provided by Dr Åke Bergman (Department of Environmental Chemistry, Stockholm University).

Determination of lymphocyte muscarinic receptor binding-On the day of the analysis, lymphocytes were thawed in a thermostatic bath at $37^{\circ} \mathrm{C}$, diluted with Hank's $+2 \%$ of fetal bovine serum (FBS) + DNasi $3 \mathrm{U} \mathrm{ml}^{-1}$, centrifuged (10 min at $2000 \mathrm{rpm}$ ) and the pellet resuspended in Hank's buffer. Lymphocytes were counted using the Coulter Counter (Instrumentations Laboratory, Milan, Italy). Binding of the specific muscarinic antagonist [ $\left.{ }^{3} \mathrm{H}\right]$ QNB to lymphocytes was performed as described by Coccini et al. (2005) with slight modifications. Briefly, one million lymphocytes were incubated, in the presence or absence of $100 \mu \mathrm{M}$ atropine, with $27 \mathrm{nM}\left[{ }^{3} \mathrm{H}\right]$ QNB in Hank's buffer ( $0.5 \mathrm{ml}$ total volume) using 96well plates. Following $60 \mathrm{~min}$ incubation at $27^{\circ} \mathrm{C}$, the reaction was stopped by adding $2 \mathrm{ml}$ of ice-cold phosphate-buffered saline (PBS). Samples were rapidly filtered through Unifilter GF/C 96-well plates using a Unifilter cell harvester (Packard, Milan, Italy) and washed three times with ice-cold PBS. Then Unifilter plate wells were air dried and counted for radioactivity in $100 \mu \mathrm{l}$ of Microscint (Packard) in a Top Count NXT (Packard) scintillation counter. Each sample was assayed in triplicate and data were expressed as fmol $10^{-6}$ cells.

Determination of platelet MAO-B activity-On the day of the analysis, PRP was thawed and the platelets were isolated by centrifugation at $500 \mathrm{~g}$ for $10 \mathrm{~min}$, re-suspended in 
$\mathrm{Na}^{+} / \mathrm{K}^{+}$phosphate buffer $(5 \mathrm{mM}) \mathrm{pH} 7.4$ and counted by Coulter Counter (Instrumentations Laboratory, Milan, Italy). Following centrifugation at $16000 \mathrm{~g}$ for $10 \mathrm{~min}$, the pellet was resuspended in the same $\mathrm{Na}^{+} / \mathrm{K}^{+}$phosphate buffer supplemented with $5 \%$ bovine serum albumin, $10 \mathrm{mM}$ dithiothreitol and $2.5 \mathrm{mM}$ EDTA, homogenized for $20 \mathrm{~s}$, and further diluted with buffer to a concentration of $20 \times 10^{6}$ platelets $/ 0.4 \mathrm{ml}$. The activity of MAO-B was determined radiochemically in duplicate samples as described by Coccini et al. (2002) using $10 \mu \mathrm{M}{ }^{14} \mathrm{C}$-PEA as the substrate. Specific activity was determined in the presence of $100 \mu \mathrm{M}$ pargyline hydrochloride. The reaction mixture contained $0.4 \mathrm{ml}$ of tissue homogenate in a final assay volume of $1 \mathrm{ml}$. The reaction was started by addition of the ${ }^{14} \mathrm{C}$ PEA and stopped by adding $0.25 \mathrm{ml} \mathrm{HCl}(4 \mathrm{~N})$ after a 10 min-incubation at $37^{\circ} \mathrm{C}$.

Deaminated reaction products were toluene-extracted and the radioactivity contained in a 1$\mathrm{ml}$ aliquot of the organic phase was counted by a scintillation counter. The activity of the enzyme was expressed as nmol $\mathrm{mg}^{-1}$ protein $\mathrm{h}^{-1}$. The mean platelet protein concentrations in platelet homogenate were $0.187 \pm 0.029 \mathrm{mg} \mathrm{ml}^{-1}$.

In vitro studies on control blood cells-Platelets or lymphocytes obtained from control healthy subjects (enrolled from the blood donor centre of the IRCCS Policlinico S. Matteo Hospital, Pavia, Italy) were treated in vitro with MeHg or selected PCB congeners to determine the LOAEL and concentration-response relationships for the biochemical parameters (MAO-B and $\mathrm{mAChRs}$ ) tested. These studies included experiments examining the concentration-response curves for individual PCB congeners in the presence/absence of a fixed concentration of $\mathrm{MeHg}$. Pilot concentration-response assays with $\mathrm{MeHg}$ alone (from $10 \mathrm{nM}$ to $1 \mathrm{mM}$ ) were performed to define the suitable fixed $\mathrm{MeHg}$ concentration ( $\left[{ }^{3} \mathrm{H}\right] \mathrm{QNB}-$ binding inhibition or MAO-B activity inhibition not higher than $20-40 \%$ ) to be used for the combined exposure experiments (Coccini et al. 2007a). Application of $\mathrm{MeHg}$ alone inhibited the in vitro ${ }^{3} \mathrm{H}-\mathrm{QNB}$ binding to lymphocyte $\mathrm{mAChRs}$ with $\mathrm{IC}_{50}$ value (mean $\pm \mathrm{SE}$ ) of $5.0 \pm 0.9 \mu \mathrm{M}$, while the inhibitory effect of $\mathrm{MeHg}$ on MAO-B activity was negligible. Based on these results MeHg concentrations of $1 \mu \mathrm{M}$ and $1 \mathrm{mM}$ were used for the combined in vitro $\mathrm{MeHg}-\mathrm{PCB}$ studies of $\mathrm{mAChRs}$ and MAO-B, respectively. PCB congeners and 4-OH-PCB-107 were tested at concentrations ranging from $10 \mathrm{nM}$ to 100 $\mu \mathrm{M}$. The $\mathrm{IC}_{50}$ values (the concentration necessary to reduce specific binding of $\left[{ }^{3} \mathrm{H}\right] \mathrm{QNB}$ or MAO-B activity by 50\%) for individual compounds alone and in combination with a fixed amount of MeHg, were calculated from concentration-response curves in which percentage inhibition was plotted against the natural logarithm of the molar PCB concentration.

Internal quality control-A pooled human lymphocyte or platelet preparation, taken as the internal quality control, was tested in each assay along with the unknown samples as a measure of quality assurance. The intra-assay variation (CV) was $<10 \%$ for MAO-B activity and 10-20\% for mAChR binding calculated on assayed $n=3-6$ replicates of different aliquots of the same platelet or lymphocyte pool. The coefficient of variation for the interassay precision ranged between 10 and $20 \%$ for both tests.

\section{Neuropsychological tests}

Examinations were conducted using an extensive neurodevelopmental test battery similar to the one employed in a previous prospective epidemiology study (Grandjean et al. 1997). The 
neuropsychological tests were selected, based on past experience, to cover several functional domains thought to be vulnerable to developmental neurotoxicity:

- Lateralization: square checking;

- Language: WISC-R Similarities, Boston Naming Test, NEPSY Speeded Naming;

- Spatial: NEPSY Route Finding, Stanford-Binet Copying, WISC-R Block Designs;

- Attention, Concentration and Executive: WISC-R Digit Spans, California Verbal Learning - Children trial 1, NES2 Continuous Performance Test, NEPSY Auditory Attention and Auditory Response;

- Manual-Motor: NES2 Finger Tapping, Santa Ana pegboard;

- Learning \& Memory: California Verbal Learning - Children, Stanford-Binet Copying recall.

In addition, the Neurological Optimality Scale was determined (Steuerwald et al. 2000).

\section{Statistical analysis}

Standard descriptive statistics were applied to raw and transformed values for mAChRs and for MAO-B and exposure data. Exposure and neurochemical data were compared by regression analysis. The results of neurobehavioural outcomes, biomarkers and prenatal $\mathrm{MeHg}$ and PCB exposures were evaluated in separate multiple regression analyses with confounder correction. We adjusted for effects of the child's age, sex, preferred hand when writing, maternal Raven score and the Home score. Tasks performed on a computer were also adjusted for the child's experience with computer games. Standardized coefficients (in regard to the standard deviation) were calculated as previously described (Grandjean et al. 1999).

\section{Results}

\section{Neurochemical markers and toxicant exposure}

The lymphocyte mAChR binding and platelet MAO-B activity measured in the blood of Faroese children are shown in the Figures 1 and 2. The distributions of $\mathrm{mAChR}$ binding in girls $(n=66)$ and boys $(n=73)$ are illustrated in Figures $1 \mathrm{~A}$ and $\mathrm{B}$, respectively. mAChR binding was similar in girls and boys ranging from 0.05 to $35.91 \mathrm{fmol} / \mathrm{million}$ cells in girls and from 0.04 to $36.78 \mathrm{fmol} /$ million cells in boys. Both genders also exhibited similar distribution for MAO-B activity (Figure 2A, B), the values ranging from 1.57 to 14.95 and from 0.95 to $14.57 \mathrm{nmol} \mathrm{mg}^{-1}$ protein $\mathrm{h}^{-1}$ for girls $(n=67)$ and boys $(n=70)$, respectively.

As described previously (Steuerwald et al. 2000), analysis of $\mathrm{Hg}$ in maternal hair indicated levels above $10 \mu \mathrm{g} \mathrm{Hg} \mathrm{g}^{-1}\left(50 \mathrm{nmol} \mathrm{g}^{-1}\right)$ in 15 samples (10.4\%) from this cohort, a limit thought to be associated with a definite risk of fetal neurotoxicity. The highest concentration was more than 100-fold greater than the lowest. Cord blood concentrations likewise showed a wide range (Table 1). The sum of all PCB congeners detected in maternal serum showed a geometric mean of $1.12 \mu \mathrm{g} \mathrm{g}^{-1}$ lipid, with a wide range of 0.04-18.4 $\mathrm{\mu g} \mathrm{g}^{-1}$ (Table 1). For comparison, available data from general population groups in the European Union generally 
indicate PCB concentrations below $0.5 \mu \mathrm{g} \mathrm{g}^{-1}$ lipid in serum and milk (IPCS 1993). Thus, the birth cohort includes moderate exposures with a built-in control group with low-level exposure.

Distribution summaries of the exposure and neurochemical markers are given in Table 1. No correlation (by regression analysis) was found between any of the exposure parameters and the neurochemical markers examined.

\section{Neuropsychological outcomes and markers of exposure and of neurotoxicity}

The neuropsychological endpoints evaluated in this cohort indicated $\mathrm{Hg}$-associated deficits similar to those observed in the previous cohort study, with minimal evidence of interference from PCB exposure ( unpublished data).

The correlation of neuropsychological data with neurotoxicity markers was estimated using multiple regression methods with adjustment for potential confounders. MAO-B and $\mathrm{mAChR}$ did not require log transformation and a linear dose-effect function was assumed for these variables. Table 2 shows the test score change in percent of test score standard deviation associated with a one unit increase exposure. The associations with neuropsychological outcomes did not show any significant correlations for the MAO-B results or for the mAChRs.

\section{Results of in vitro studies on control blood cells}

Lymphocyte mAChR binding-The LOAEL and $\mathrm{IC}_{50}$ concentrations of MeHg toward to $\mathrm{mAChRs}$ were $1 \mu \mathrm{M}$ and $5 \mu \mathrm{M}$, respectively. As shown in Figure 3A, there were no significant differences between the individual PCBs tested regarding their $\mathrm{IC}_{50}$ values and these values were not modified by addition of $\mathrm{MeHg}$. The $\mathrm{IC}_{50} \mathrm{PCB}$ values were considerably high (from 20 to $60 \mu \mathrm{M}$ ) indicating a negligible direct effect of these agents on $\mathrm{mAChR}$ binding either in the presence or absence of MeHg. The LOAEL values toward mAChRs were $0.1 \mu \mathrm{M}$ for PCB-77 and $1 \mu \mathrm{M}$ for PCB-28, PCB-105, PCB-118, PCB-153 and 4-OH-PCB-107, respectively (regardless of the presence of $\mathrm{MeHg}$ ).

Platelet MAO-B-Most of the compounds tested had a modest effect on MAO-B activity with $\mathrm{IC}_{50}$ values ranging from 30 to $50 \mu \mathrm{M}$. No effect was observed in samples treated with PCB-153 (Figure 3B). The direct action of PCBs and PCB-MeHg mixtures on MAO-B activity was negligible even in preparations treated with $\mathrm{MeHg}$ at concentrations up to 1 $\mathrm{mM}$. The PCB LOAEL values toward MAO-B were $1 \mu \mathrm{M}$ for PCB-105 and $10 \mu \mathrm{M}$ for PCB-28, PCB-77, PCB-118 and 4-OH-PCB-107, respectively. These values were not modified by $\mathrm{MeHg}$ addition.

In summary, the in vitro data indicated that the PCB congeners and 4-OH-PCB-107 have a modest or negligible direct effect on lymphocyte $\mathrm{mAChR}$ binding as well as on platelet MAO-B activity. 


\section{Discussion}

In this study, two neurochemical blood markers ( $\mathrm{mAChRs}$ and MAO-B) were measured in a cohort of 7-year-old children with widely different degrees of $\mathrm{MeHg}$ exposure. The results indicated no association of either of these markers with $\mathrm{Hg}$ exposure or a series of neuropsychological endpoints similar to those examined in a previous study in children at 7 years of age (Grandjean et al. 1997). Similarly, no association was observed when PCB levels were taken into consideration as exposure markers for the statistical analyses. Previous animal studies have provided convincing evidence that both monoaminergic and cholinergic systems are sensitive targets for MeHg and PCB neurotoxicity (Johansson et al. 2007, Castoldi et al. 2008a, b). The results of the present study suggest that peripheral MAO-B and mAChRs may be not sensitive enough for assessing subclinical effects of $\mathrm{MeHg}$ and/or PCBs at low/moderate exposure conditions.

In contrast, the bulk of human literature data has indicated typical alteration of these parameters when used as peripheral indicators of the brain neurochemistry changes associated with neuropsychiatric disorders (Danielczyk et al. 1988, Perry \& Hodges 1999, Sandler et al. 1981) and drug dependence (Anthenelli et al. 1995, Sullivan et al. 1990, Coccini et al. 2002, Snell et al. 2002), or as predictors of pharmacological response in subjects treated with psychotropic drugs and other classes of pharmaceutical agents (Eriksson et al. 2006, Muck-Seler et al. 2008).

Low platelet MAO activity has been associated with a variety of pathologies including schizophrenia, obsessive-compulsive states, borderline personality disorder (Kaneda et al. 2001, Meltzer \& Zureick 1987, Murphy \& Wyatt 1972, Arrojo et al. 2007, Verkes et al. 1998), pathological gambling (Blanco et al. 1996) and bulimia (Carrasco et al. 2000). Inhibition of MAO activity can affect learning and memory (Gelowitz et al. 1994, Holschneider et al. 2001). Other studies have indicated alteration in platelet MAO-B activity in Alzheimer's (AD) and Parkinson's diseases (Riederer et al. 2004) and posttraumatic stress disorders (Pivac et al. 2007). Altered lymphocyte mAChR binding has been reported in AD (Tayebati et al. 1999, 2001), Parkinson's (Rabey et al. 1991) and Meniere's diseases (Masuyama et al. 1996), as well as in Gilles de la Tourette syndrome (Rabey et al. 1992). There is convincing evidence that changes in these peripheral blood cell parameters often mirror a defective balance of central neurotransmitter systems (Manzo et al. 2001, Oreland et al. 2007). Notably, brain cholinergic and monoaminergic pathways are known to be critically involved in cognitive function, learning, attention and affective behaviour as well as in neurodevelopmental processes (Leblond et al. 2002, Griffin et al. 2003, Prado et al. 2006, Wess et al. 2007).

There are also examples of application of platelet MAO-B as a indicator of neurotransmission changes in subjects exposed to occupational or environmental neurotoxicants. A cross-sectional study of boat plant workers demonstrated that MAO-B in the platelets was inversely related to styrene exposure (Checkoway et al. 1994). A relationship between platelet MAO-B and $\mathrm{Hg}$ exposure was described in adults from a fisheating population living along the St Lawrence River (Lake St Pierre, Quebec, Canada) (Stamler et al. 2006). In these subjects, a negative association was established between 
platelet MAO-B activity and blood-Hg concentrations above $3.4 \mu \mathrm{g} \mathrm{l} \mathrm{l}^{-1}$ (75th percentile) but no attempts were made to determine whether or not the low MAO activity was associated with neurological changes. In our previous studies, a variety of neuropsychological endpoints (identical to those tested in the present cohort) were examined in Faroese children prenatally exposed to $\mathrm{MeHg}$ (Grandjean et al. 1997). The total range of $\mathrm{Hg}$ concentrations in blood were 0.9-351 $\mu \mathrm{g} \mathrm{l}^{-1}$ and 0.26-39.9 $\mu \mathrm{g} \mathrm{l}^{-1}$ for cord blood and child blood, respectively. This cohort included children with high $\mathrm{Hg}$ levels also showing neurobehavioural alterations.

Significant changes in platelet MAO-B activity and lymphocyte mAChRs have also been described in laboratory animals treated with relatively high doses of $\mathrm{MeHg}$ and other chemicals. For example, cerebral and lymphocyte mAChR binding was similarly modified by treatments with cholinergic agonist or antagonist drugs (Costa et al. 1990) as well as by MeHg (Coccini et al. 2000) and organophosphorus insecticides (Fitzgerald \& Costa 1993). Changes in mAChRs were also observed in developing rats exposed perinatally to $\mathrm{MeHg}$ (Coccini et al. 2007a) or to mixtures of MeHg and PCBs (Coccini et al. 2007b). In other experiments, reduced brain MAO-B was observed in weaning rats that had been exposed to $\mathrm{MeHg}$ alone or in combination with PCB-153 (Castoldi et al. 2006). The perinatal MeHg dose that produced changes in cholinergic and aminergic systems was $1 \mathrm{mg} \mathrm{MeHg} \mathrm{kg}{ }^{-1}$ daily whereas treatment with $0.5 \mathrm{mg} \mathrm{MeHg} \mathrm{kg}{ }^{-1}$ daily was ineffective. The $\mathrm{Hg}$ concentrations measured in weaning rats given $1 \mathrm{mg} \mathrm{MeHg} \mathrm{kg}^{-1}$ daily were 1.5-2.8 ppm in the brain (Coccini et al. 2007b) and $1.3 \pm 0.4 \mu \mathrm{g} \mathrm{ml}^{-1}$ in the blood (Coccini et al. 2007a). These concentrations were 45-260 times higher compared with $\mathrm{Hg}$ levels found in cord blood and 7-year-old children blood of the present cohort (27.6 and $5.27 \mathrm{ppb}$, respectively).

These observations suggest that the ability of $\mathrm{MeHg}$ to alter central and peripheral markers of neurotransmission may vary according to exposure levels. This is also indicated by our in vitro experiments. In lymphocytes directly exposed to MeHg in vitro, the LOAEL and $\mathrm{IC}_{50}$ values of MeHg toward mAChRs were $1 \mu \mathrm{M}$ and $5 \mu \mathrm{M}$, respectively. Co-exposure with various PCB congeners (both dioxin and non-dioxin-like congeners) did not modify the in vitro response of $\mathrm{mAChR}$ to $\mathrm{MeHg}$. Notably, $\mathrm{Hg}$ levels in the order of about $5 \mu \mathrm{M}$ were measured in rat brain and blood after in vivo perinatal exposure to $1 \mathrm{mg} \mathrm{MeHg} \mathrm{kg}^{-1}$ daily (Coccini et al. 2007a, b).

The variability of the biomarkers cannot be ascribed as one of the major reason for the lack of association with the blood $\mathrm{Hg}$ levels which comprise a wide range of values, including those similar or even higher to the benchmark dose lower limits (NRC 2000), for instance $\geq 58 \mathrm{ppb}$ for $\mathrm{Hg}$ in cord blood and $\geq 12 \mathrm{ppm}$ for $\mathrm{Hg}$ in maternal hair. Indeed, the use of these biomarkers have been shown to be appropriate for evaluating and monitoring abusable or pharmaceutical drugs in several clinical settings.

To our knowledge, this work is one of the few examples of application of biomarkers of neurotoxicity to human exposure in a non-occupational setting. The study investigated a large number of subjects by validated techniques that were applied in compliance with standard Quality Assurance System criteria of clinical chemistry. 
However, there are some limitations in the study to be considered. First, our experiments have focused on total $\mathrm{mAChR}$ density while specific $\mathrm{mAChR}$ subtypes are likely implicated in central nervous system (CNS) disorders (Wess et al. 2007). Second, confounding factors, such as genetic variables (Oreland \& Fowler 1982, Oreland et al. 2007, Dick et al. 2007, Gosso et al. 2006) that are known to affect these biochemical parameters in neuropsychological illness, may have contributed as response modifiers of the children exposed to MeHg. As already discussed, MAO-B and mAChRs are useful in a medical setting when applied to corroborate clinical findings in patients suffering from frank nervous system disorders or to evaluate and monitor the effect of pharmaceutical or abusable drugs. Our data suggest that these markers may exhibit insufficient sensitivity when used in epidemiological studies assessing the effects of retrospective low-level exposure to neurotoxicants, especially if variability in exposure over time and between individuals of the population studied is large.

Finally, age-dependent variables need to be considered. The precise time point at which peripheral MAO-B and mAChRs may become predictive of neuropsychological outcomes in children (noticeable later in life) is uncertain. Ideally, these neurochemical parameters (and their correlation with neuropsychological outcomes) should be determined both at early (e.g. cord blood) and late time points in the same subject. This approach would be useful to avoid artefactual results due to the blood cell turnover in exposures that have occurred at vulnerable time windows (for example in utero) years before biochemical testing.

\section{Acknowledgments}

The present study was part of projects supported by the European Commission (ANEMONE - QLK4CT-2001-00186, Quality of Life and Management of Living Resources Programme) and the Italian Ministry of Health. Professor Åke Bergman (Stockholm University) kindly provided the PCB congeners that were synthesized in his laboratory. The authors wish to thank Mr Davide Acerbi for his excellent technical assistance.

\section{References}

Anthenelli RM, Smith TL, Craig CE, Tabakoff B, Schuckit MA. Platelet monoamine oxidase activity levels in subgroups of alcoholics: diagnostic, temporal, and clinical correlates. Biol Psychiatry. 1995; 38:361-368. [PubMed: 8547455]

Arrojo M, Baca-Garcia E, Perez-Rodriguez MM, Dolengevich-Segal H, Navio-Acosta M, RodriguezSalgado B, Saiz-Ruiz J. Platelet monoamine oxidase activity in obsessive-compulsive disorder. Eur Psychiatry. 2007; 22:525-529. [PubMed: 17761404]

Basu N, Stamler CJ, Loua KM, Chan HM. An interspecies comparison of mercury inhibition on muscarinic acetylcholine receptor binding in the cerebral cortex and cerebellum. Toxicol Appl Pharmacol. 2005; 205:71-76. [PubMed: 15885266]

Beyrouty P, Stamler C, Liu JN, Kubow S, Chan HM. Effects of prenatal methylmercury exposure on brain monoamine oxidase activity and neurobehavior of rats. Neurotoxicol Teratol. 2006; 28:251259. [PubMed: 16490344]

Blanco C, Orensanz-Munoz L, Blanco-Jerez C, Saiz-Ruiz J. Pathological gambling and platelet MAO activity: a psychobiological study. Am J Psychiatry. 1996; 153:119-121. [PubMed: 8540570]

Carrasco JL, Diaz-Marsa M, Hollander E, Cesar J, Saiz-Ruiz J. Decreased platelet monoamine oxidase activity in female bulimia nervosa. Eur Neuropsychopharmacol. 2000; 10:113-117. [PubMed: 10706992]

Castoldi AF, Candura SM, Costa P, Manzo L, Costa LG. Interaction of mercury compounds with muscarinic receptor subtypes in the rat brain. Neurotoxicology. 1996; 17:735-742. [PubMed: 9086496] 
Castoldi AF, Blandini F, Randine G, Samuele A, Manzo L, Coccini T. Brain monoaminergic neurotransmission parameters in weanling rats after perinatal exposure to methylmercury and $2,2^{\prime}$, 4,4',5,5'-hexachlorobiphenyl (PCB153). Brain Res. 2006; 1112:91-98. [PubMed: 16904659]

Castoldi AF, Johansson C, Onishchenko N, Coccini T, Roda E, Vahter M, Ceccatelli S, Manzo L. Human developmental neurotoxicity of methylmercury: Impact of variables and risk modifiers. Regul Toxicol Pharmacol. 2008a; 51:201-214. [PubMed: 18367301]

Castoldi AF, Onishchenko N, Johansson C, Coccini T, Roda E, Vahter M, Ceccatelli S, Manzo L. Neurodevelopmental toxicity of methylmercury: laboratory animal data and their contribution to human risk assessment. Regul Toxicol Pharmacol. 2008b; 51:215-229. [PubMed: 18482784]

Chakrabarti SK, Loua KM, Bai C, Durham H, Panisset J-C. Modulation of monoamine oxidase activity in different brain regions and platelets following exposure of rats to methylmercury. Neurotoxicol Teratol. 1998; 20:161-168. [PubMed: 9536461]

Checkoway H, Echeverria D, Moon J-D, Heyer N, Costa LG. Platelet monoamine oxidase B activity in workers exposed to styrene. Int Arch Occup Environ Health. 1994; 66:359-362. [PubMed: 7896422]

Chen K, Wu HF, Shih JC. The deduced amino acid sequences of human platelet and frontal cortex monoamine oxidase B are identical. J Neurochem. 1993; 61:187-190. [PubMed: 8515265]

Coccini T, Castoldi AF, Gandini C, Randine G, Vittadini G, Baiardi P, Manzo L. Platelet monoamine oxidase B activity as a state marker for alcoholism: trend over time during withdrawal and influence of smoking and gender. Alcohol Alcohol. 2002; 37:566-572. [PubMed: 12414548]

Coccini T, Randine G, Castoldi AF, Acerbi D, Manzo L. Methylmercury interaction with lymphocyte cholinergic muscarinic receptors in developing rats. Environ Res. 2007a; 103:229-237. [PubMed: 16808911]

Coccini T, Roda E, Castoldi AF, Goldoni M, Poli D, Bernocchi G, Manzo L. Perinatal co-exposure to methylmercury and PCB153 or PCB126 in rats alters the cerebral cholinergic muscarinic receptors at weaning and puberty. Toxicology. 2007b; 238:34-48. [PubMed: 17618726]

Coccini T, Randine G, Candura SM, Nappi R, Prockop LD, Manzo L. Low-level exposure to methylmercury modifies muscarinic cholinergic receptor binding characteristics in rat brain and lymphocytes: physiologic implications and new opportunities in biological monitoring. Environ Health Perspect. 2000; 108:29-33. [PubMed: 10620521]

Coccini T, Randine G, Castoldi AF, Balloni L, Baiardi P, Manzo L. Lymphocyte muscarinic receptors and platelet monoamine oxidase-B as biomarkers of CNS function. Effects of age and gender in healthy humans. Environ Toxicol Pharmacol. 2005; 19:715-720. [PubMed: 21783547]

Coccini T, Randine G, Castoldi AF, Grandjean P, Ostendorp G, Heinzow B, Manzo L. Effects of developmental co-exposure to methylmercury and 2,2',4,4',5,5'-hexachlorobiphenyl (PCB153) on cholinergic muscarinic receptors in rat brain. Neurotoxicology. 2006; 27:468-477. [PubMed: 16455139]

Costa LG, Kaylor G, Murphy SD. In vitro and in vivo modulation of cholinergic muscarinic receptors in rat lymphocytes and brain by cholinergic agents. Int J Immunopharmacol. 1990; 12:67-75. [PubMed: 2303319]

Danielczyk W, Streifler M, Konrad C, Riederer P, Moll G. Platelet MAO-B activity and the psychopathology of Parkinson's disease, senile dementia and multi-infarct dementia. Acta Psychiatr Scand. 1988; 78:730-736. [PubMed: 3223331]

Dick DM, Aliev F, Kramer J, Wang JC, Anthony Hinrichs A, Bertelsen S, Kuperman S, Schuckit M, Nurnberger J Jr, Edenberg HJ, Porjesz B, Begleiter H, Hesselbrock V, Goate A, Bierut L. Association of CHRM2 with IQ: Converging evidence for a gene influencing intelligence. Behav Genet. 2007; 37:265-272. [PubMed: 17160701]

Donnelly CH, Murphy DL. Substrate- and inhibitor-related characteristics of human platelet monoamine oxidase. Biochem Pharmacol. 1977; 26:853-858. [PubMed: 861051]

Eriksson P, Lundkvist U, Fredriksson A. Neonatal exposure to 3,3',4,4'-tetrachlorobiphenyl: changes in spontaneous behaviour and cholinergic muscarinic receptors in the adult mouse. Toxicology. 1991; 69:27-34. [PubMed: 1926153] 
Eriksson M, Berggren U, Fahlke C, Engel J, Balldin J. Platelet monoamine oxidase B (MAO-B) activity and its relationship to DL-fenfluramine-induced prolactin response in healthy men. $\mathbf{J}$ Neural Transm. 2006; 113:33-41. [PubMed: 15959855]

Fitzgerald BB, Costa LG. Modulation of muscarinic receptors and acetylcholinesterase activity in lymphocytes and in brain areas following repeated organophosphates exposure in rats. Fundam Appl Toxicol. 1993; 20:210-216. [PubMed: 8449393]

Fowler CJ, Tipton KF, MacKay AVP, Youdim MBH. Human platelet monoamine oxidase: a useful enzyme in the study of psychiatric disorders? Neuroscience. 1982; 7:1577-1594. [PubMed: 6956813]

Gelowitz DL, Richardson JS, Wishart TB, Yu PH, Lai CT. Chronic L-deprenyl or L-amphetamine: equal cognitive enhancement, unequal MAO inhibition. Pharmacol Biochem Behav. 1994; 47:4145. [PubMed: 8115427]

Gosso MF, van Belzen M, de Geus EJ, Polderman JC, Heutink P, Boomsma DI, Posthuma D. Association between the CHRM2 gene and intelligence in a sample of 304 Dutch families. Genes Brain Behav. 2006; 5:577-584. [PubMed: 17081262]

Grandjean P, Weihe P, Burse VW, Needham LL, Storr-Hansen E, Heinzow B, Debes F, Murata K, Simonsen H, Ellefsen P, Budtz-Jørgensen E, Keiding N, White RF. Neurobehavioral deficits associated with PCB in 7-year-old children prenatally exposed to seafood neurotoxicants. Neurotoxicol Teratol. 2001; 23:305-317. [PubMed: 11485834]

Grandjean P, Weihe P, White RF, Debes F, Araki S, Yokoyama K, Murata K, Sørensen N, Dahl R, Jørgensen PJ. Cognitive deficit in 7-year-old children with prenatal exposure to methylmercury. Neurotoxicol Teratol. 1997; 19:417-428. [PubMed: 9392777]

Grandjean P, Budtz-Jørgensen E, White RF, Jørgensen PJ, Weihe P, Debes F, Keiding. Methylmercury exposure biomarkers as indicators of neurotoxicity in children aged 7 years. Am J Epidemiol. 1999; 150:301-305. [PubMed: 10430235]

Grandjean P, Budtz-Jørgensen E, Jørgensen PJ, Weihe P. Umbilical cord mercury concentration as biomarker of prenatal exposure to methylmercury. Environ Health Perspect. 2005; 113:905-908. [PubMed: 16002381]

Grandjean P, Landrigan PJ. Developmental neurotoxicity of industrial chemicals. Lancet. 2006; 368:2167-2178. [PubMed: 17174709]

Griffin SL, van Reekum R, Masanic C. A review of cholinergic agents in the treatment of neurobehavioral deficits following traumatic brain injury. J Neuropsychiatr Clin Neurosci. 2003; 15:17-26.

Holschneider DP, Chen K, Seif I, Shih JC. Biochemical, behavioral, physiologic, and neurodevelopmental changes in mice deficient in monoamine oxidase A or B. Brain Res Bull. 2001; 56:453-462. [PubMed: 11750790]

IPCS. Environmental Health Criteria. 2. Geneva: World Health Organization; 1993. Polychlorinated Biphenyls and Terphenyls; p. 140

Jacobson JL, Jacobson SW. Teratogen update: polychlorinated biphenyls. Teratology. 1997; 55:338347. [PubMed: 9261928]

Johansson C, Castoldi AF, Onishchenko N, Manzo L, Vahter M, Ceccatelli S. Neurobehavioural and molecular changes induced by methylmercury exposure during development. Neurotox Res. 2007; 11:241-260. [PubMed: 17449462]

Kaneda Y, Fujii A, Nagamine I. Platelet serotonin concentrations in medicated schizophrenic patients. Prog Neuropsychopharmacol Biol Psychiatry. 2001; 25:983-992. [PubMed: 11444685]

Leblond L, Beaufort C, Delerue F, Durkin TP. Differential roles for nicotinic and muscarinic cholinergic receptors in sustained visuo-spatial attention? A study using a 5-arm maze protocol in mice. Behav Brain Res. 2002; 128:91-102. [PubMed: 11755693]

Limke TL, Heidemann SR, Atchison WD. Disruption of intraneuronal divalent cation regulation by methylmercury: are specific targets involved in altered neuronal development and cytotoxicity in methylmercury poisoning? Neurotoxicology. 2004; 25:741-760. [PubMed: 15288506]

Manzo L, Artigas F, Martinez E, Mutti A, Bergamaschi E, Nicotera P, Tonini M, Candura SM, Ray DE, Costa LG. Biochemical markers of neurotoxicity. A review of mechanistic studies and applications. Hum Exp Toxicol. 1996; 15:S20-S35. [PubMed: 8882557] 
Manzo L, Castoldi AF, Coccini T, Prockop LD. Assessing effects of neurotoxic pollutants by biochemical markers. Environ Res A. 2001; 85:31-36.

Masuyama K, Uno K, Minoda R, Eura M, Samejima Y, Ishikawa T. Muscarinic acetylcholine receptors in patients with Meniere's disease. Acta Oto-Laryngol (Stockholm). 1996; 116:369-373.

Meltzer HY, Zureick JL. Relationship of auditory hallucinations and paranoia to platelet MAO activity in schizophrenics: sex and race interactions. Psychiatry Res. 1987; 22:99-109. [PubMed: 3685225]

Muck-Seler D, Sagud M, Mustapic M, Nedic G, Babic A, Mihaljevic Peles A, Jakovljevic M, Pivac N. The effect of lamotrigine on platelet monoamine oxidase type B activity in patients with bipolar depression. Prog Neuro-Psychopharmacol Biol Psychiatry. 2008; 32:1195-1198.

Murphy DL, Wyatt RJ. Reduced monoamine oxidase activity in blood platelets from schizophrenic patients. Nature. 1972; 238:225-226. [PubMed: 4558353]

NRC, National Research Council. Toxicological effects of methylmercury. Washington DC: National Academy Press; 2000.

Oreland, L.; Fowler, C. Brain and platelet monoamine oxidase activities in relation to central monoaminergic activity in mice and man. In: Kamijo, K.; Usdin, E.; Nagatsu, T., editors. Monoamine Oxidase: Basic and Clinical Frontiers. Amsterdam: Excerpta Medica; 1982. p. 312-320.

Oreland L, Nilsson K, Damberg M, Hallman J. Monoamine oxidases - activities, genotypes and the shaping of behaviour. J Neural Transm. 2007; 114:817-822. [PubMed: 17426915]

Perry RJ, Hodges JR. Attention and executive deficits in Alzheimer's disease: a critical review. Brain. 1999; 122:383-404. [PubMed: 10094249]

Pivac N, Knezevic J, Kozaric-Kovacic D, Dezelijin M, Mustapic M, Rak D, Mitijevic T, Pavelic J, Muck-Seler D. Monoamine oxidase (MAO) intron 13 polymorphism and platelet MAO-B activity in combat-related posttraumatic stress disorders. J Affect Disord. 2007; 103:131-138. [PubMed: 17289152]

Prado VF, Martins-Silva C, de Castro BM, Lima RF, Barros DM, Amaral E, Ramsey AJ, Sotnikova TD, Ramirez MR, Kim HG, Rossato JI, Koenen J, Quan H, Cota VR, Moraes MF, Gomez MV, Guatimosim C, Wetsel WC, Kushmerick C, Pereira GS, Gainetdinov RR, Izquierdo I, Caron MG, Prado MA. Mice deficient for the vesicular acetylcholine transporter are myasthenic and have deficits in object and social recognition. Neuron. 2006; 51:601-612. [PubMed: 16950158]

Rabey JM, Grynberg E, Graff E. Changes of muscarinic cholinergic binding by lymphocyte in Parkinson's disease with and without dementia. Ann Neurol. 1991; 30:847-850. [PubMed: 1789698]

Rabey JM, Lewis A, Graff E, Korczyn AD. Decreased (3H) quinuclidinyl benzilate binding to lymphocytes in Gilles de la Tourette syndrome. Biol Psychiatry. 1992; 31:889-895. [PubMed: 1637929]

Rice DC, Barone S Jr. Critical periods of vulnerability for the developing nervous system: evidence from human and animal models. Environ Health Perspect. 2000; 108:511-531. [PubMed: 10852851]

Riederer P, Danielczyk W, Grünblatt E. Monoamine oxidase-B inhibition in Alzheimer's disease. NeuroToxicology. 2004; 25:271-277. [PubMed: 14697902]

Rodier PM. Vulnerable periods and processes during central nervous system development. Environ Health Perspect. 1994; 102:121-124. [PubMed: 7925182]

Sandler M, Reveley MA, Glover V. Human platelet monoamine oxidase activity in health and disease: a review. J Clin Pathol. 1981; 34:292-302. [PubMed: 6453137]

Snell LD, Glanz J, Tabakoff B. Relationships between effects of smoking, gender, and alcohol dependence on platelet monoamine oxidase-B: activity, affinity labelling, and protein measurements. Alcohol Clin Exp Res. 2002; 26:1105-1113. [PubMed: 12170121]

Stamler CJ, Abdelouahab N, Vanier C, Mergler D, Chan HM. Relationship between platelet monoamine oxidase-B (MAO-B) activity and mercury exposure in fish consumers from the Lake St. Pierre region of Que., Canada. Neurotoxicology. 2006; 27:429-436. [PubMed: 16494947] 
Steuerwald U, Weihe P, Jørgensen PJ, Bjerve K, Brock J, Heinzow B, Budtz-Jørgensen E, Grandjean P. Maternal seafood diet, methylmercury exposure, and neonatal neurologic function. J Pediatr. 2000; 136:599-605. [PubMed: 10802490]

Stewart PW, Reihman J, Lonky EI, Darvill TJ. Cognitive development in preschool children prenatally exposed to PCBs and MeHg. Neurotoxicol Teratol. 2003; 25:11-22. [PubMed: 12633733]

Sullivan JL, Baenziger JC, Wagner DL, Rauscher FP, Nurnberger JI Jr, Holmes JS. Platelet MAO in subtypes of alcoholism. Biol Psychiatry. 1990; 27:911-922. [PubMed: 2331498]

Tayebati SK, Codini M, Gallai V, Mannino F, Parnetti L, Ricci A, Sarchielli P, Amenta F. Radioligand binding assay of M1-M5 muscarinic cholinergic receptor subtypes in human peripheral blood lymphocytes. J Neuroimmunol. 1999; 99:224-229. [PubMed: 10505979]

Tayebati SK, Amenta F, Amici S, El-Assouad D, Gallai V, Ricci A, Parnetti L. Peripheral blood lymphocytes muscarinic cholinergic receptor subtypes in Alzheimer's disease: a marker of cholinergic dysfunction? J Neuroimmunol. 2001; 121:126-131. [PubMed: 11730949]

Verkes RJ, Van der Mast RC, Kerkhof AJ, Fekkes D, Hengeveld MW, Tuyl JP, Van Kempen GM. Platelet serotonin, monoamine oxidase activity, and $3 \mathrm{H}$ paroxetine binding related to impulsive suicide attempts and borderline personality disorder. Biol Psychiatry. 1998; 15:740-746. [PubMed: 9606528]

Vincent DR, Bradshaw WS, Booth GM, Seegmiller RE, Allen SD. Effect of PCB and DES on rat monoamine oxidase, acetylcholinesterase, testosterone and estradiol ontogeny. Bull Environ Contam Toxicol. 1992; 48:884-893. [PubMed: 1568066]

Wess J, Eglen RM, Gautam D. Muscarinic acetylcholine receptors: mutant mice provide new insights for drug development. Nature Rev Drug Discov. 2007; 6:721-733. [PubMed: 17762886]

Whitfield JB, Pang D, Bucholz KK, Madden PA, Heath AC, Statham DJ, Martin NG. Monoamine oxidase: associations with alcohol dependence, smoking and other measures of psycopathology. Psychol Med. 2000; 30:443-454. [PubMed: 10824664]

Wyatt RT, Murphy DL, Belmaker R, Cohen S, Donnelly CH, Pollin W. Reduced monoamine oxidase activity in platelets: a possible genetic marker for vulnerability to schizophrenia. Science. 1973; 179:916-918. [PubMed: 4687789]

Yuan Y, Atchison WD. Disruption by methylmercury of membrane excitability and synaptic transmission of CA1 neurons in hippocampal slices of the rat. Toxicol Appl Pharmacol. 1993; 120:203-215. [PubMed: 8511789] 
A Lymphocyte muscarinic receptor binding in female children

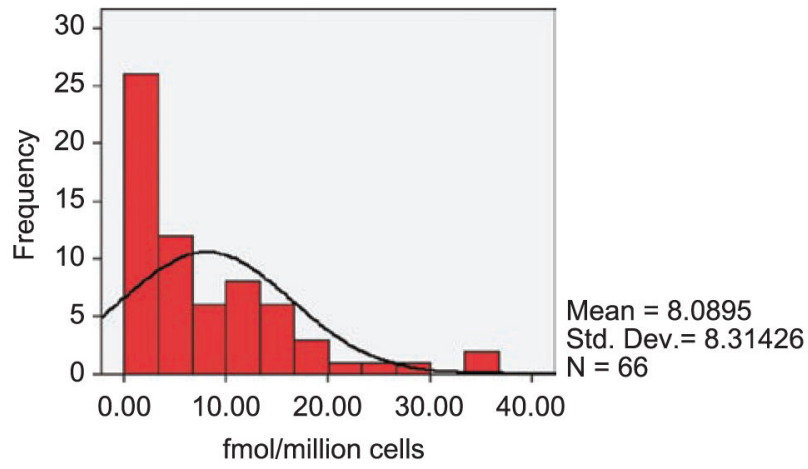

B Lymphocyte muscarinic receptor binding in male children

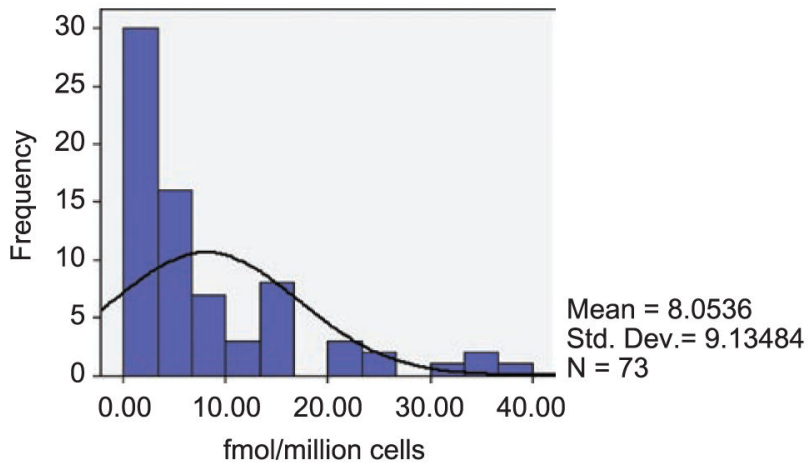

Figure 1.

Muscarinic receptor (mAChR) binding in lymphocytes from the Faroese children. (A) Females $(n=66)$, min-max: 0.05-35.91 fmol/million lymphocytes. (B) Males $(n=73)$, min-max: 0.04-36.78 fmol/million lymphocytes. 
A Platelet MAO-B activity in female children

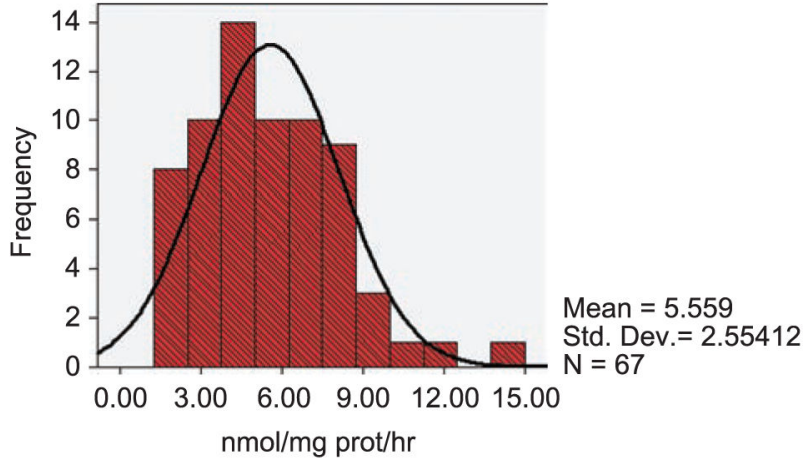

B Platelet MAO-B activity in male children

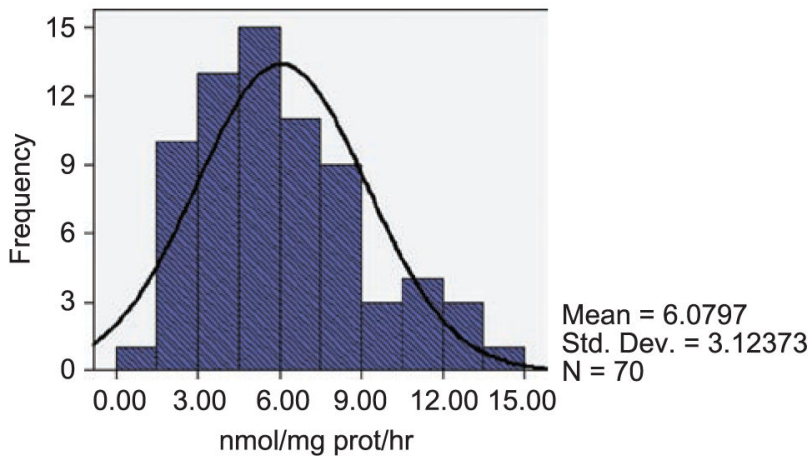

Figure 2.

Monoamine oxidase B (MAO-B) activity in platelets from the Faroese children. (A) Females $(n=67)$, min-max: $1.57-14.95 \mathrm{nmol} \mathrm{mg}^{-1}$ protein $\mathrm{h}^{-1}$. (B) Males $(n=70)$, min-max: 0.95$14.57 \mathrm{nmol} \mathrm{mg}^{-1}$ protein $\mathrm{h}^{-1}$. 
A Lymphocyte mAChR binding
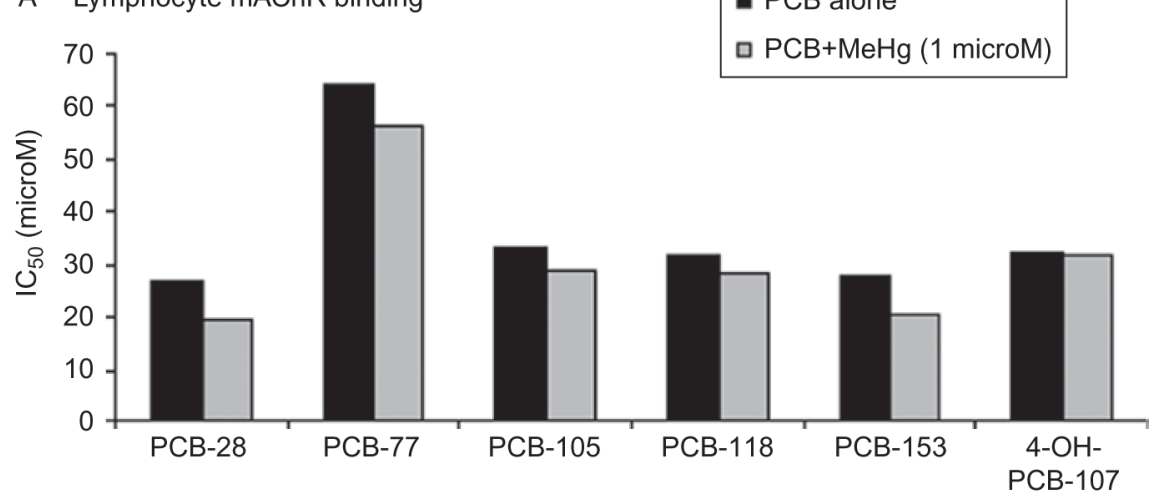

B Platelet MAO-B activity
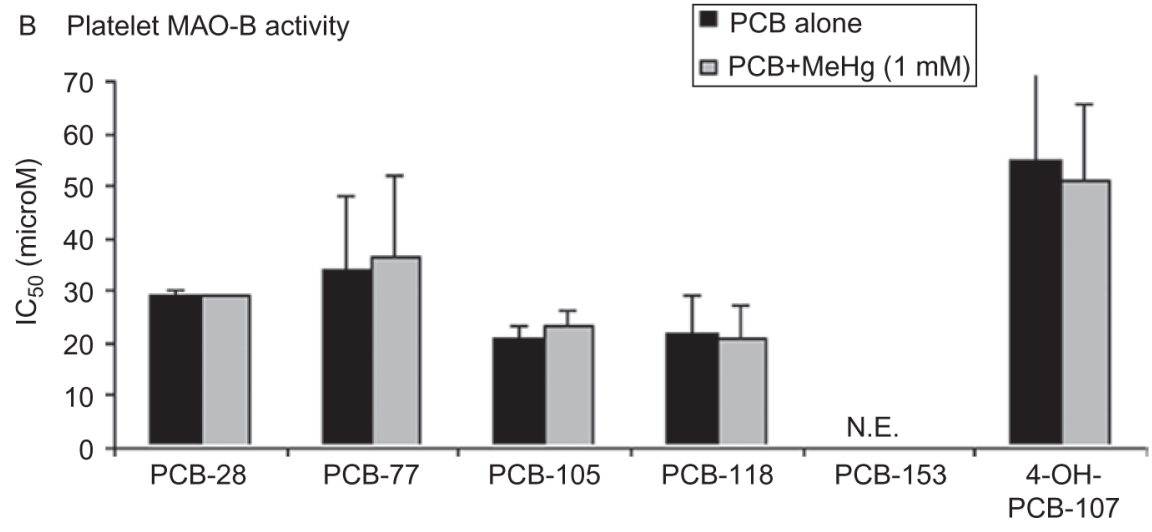

Figure 3.

$\mathrm{IC}_{50}$ (microM) values for each polychlorinated biphenyl (PCB) and 4-OH-PCB-107 in the presence or absence of a fixed concentration of methylmercury ( $\mathrm{MeHg}$ ). (A) Muscarinic cholinergic receptor ( $\mathrm{mAChR}$ ) binding in human lymphocytes. The fixed concentration of $\mathrm{MeHg}$ was 1 microM. The results are the mean of two separate experiments in which the samples were run in triplicate. (B) MAO-B activity in human platelets. The fixed concentration of $\mathrm{MeHg}$ was $1 \mathrm{mM}$. The results are the mean $\pm \mathrm{SE}$ of three separate experiments in which the samples were run in triplicate. N.E., no effect for PCB-153 was observed. 


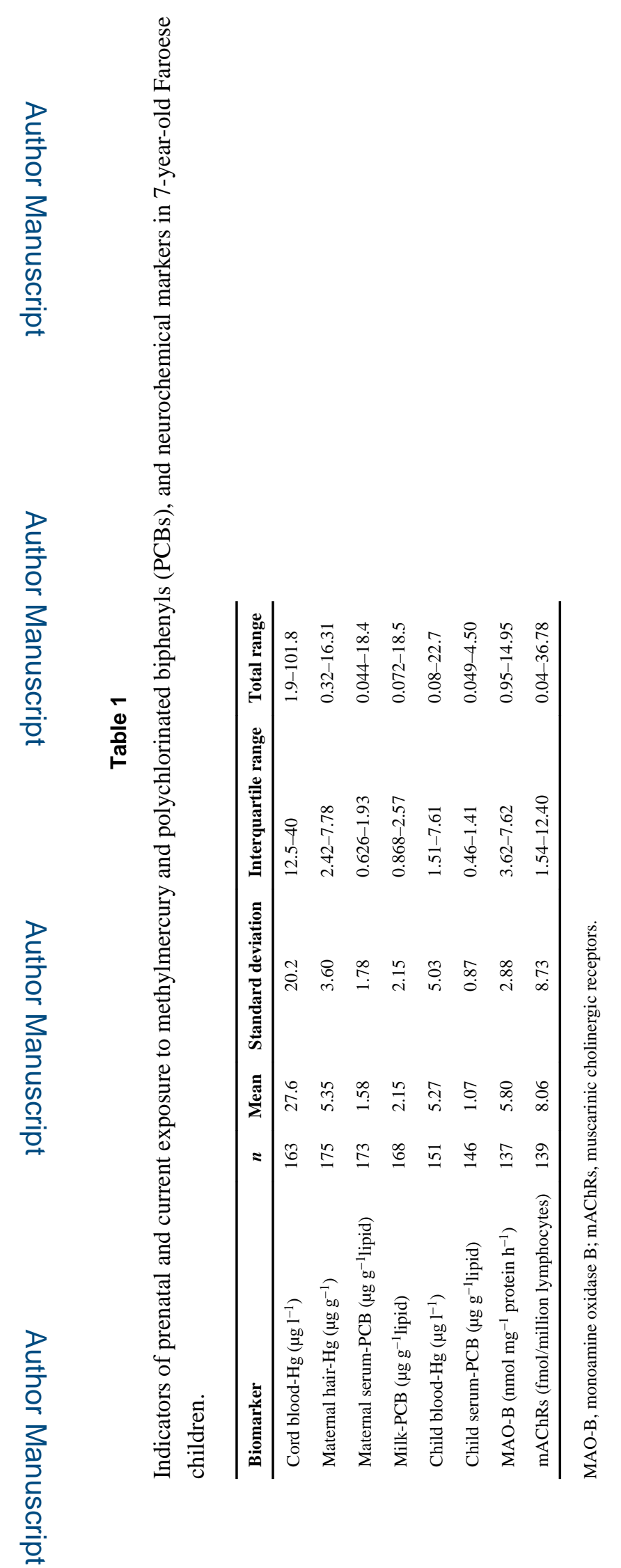

Biomarkers. Author manuscript; available in PMC 2015 April 30. 


\section{로을}

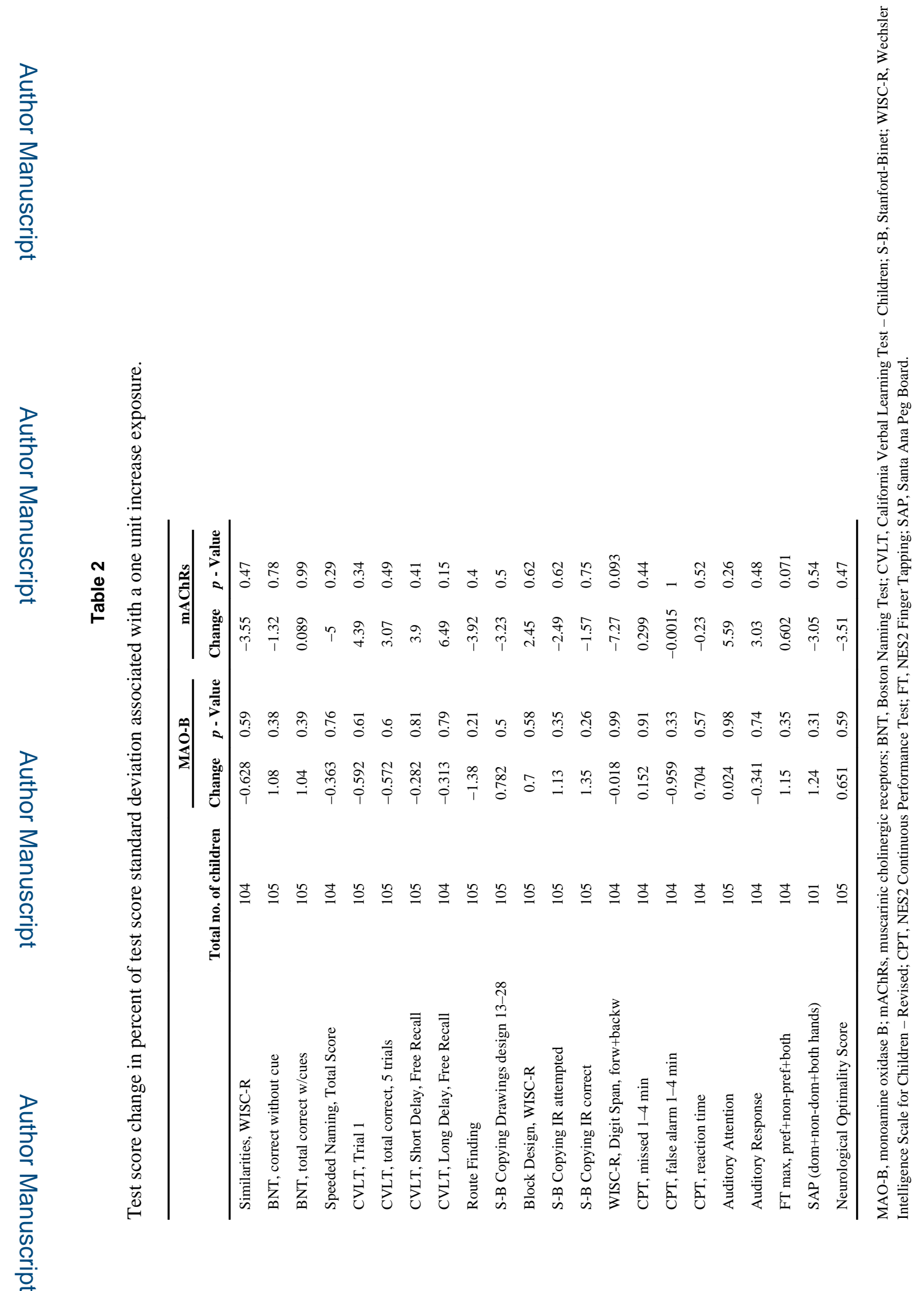

Biomarkers. Author manuscript; available in PMC 2015 April 30. 